\title{
PENGALAMAN KERJA DAN KOMPETENSI AUDITOR ATAS KUALITAS AUDIT PADA BPKP PERWAKILAN PROPINSI SUMATERA UTARA
}

\author{
Putri Kemala Dewi Lubis \\ Universitas Negeri Medan \\ Fakultas Ekonomi, Program Studi Pendidikan Ekonomi \\ Email : putrikemala@unimed.ac.id
}

\begin{abstract}
Abstrak
Penelitian ini bertujuan untuk mengetahui pengaruh pengalaman kerja dan kompetensi auditor terhadap kualitas audit. Penelitian ini menggunakan pendekatan assosiatif. Populasi pada penelitian ini adalah 116 responden auditor yang berkerja di kantor BPKP Perwakilan Provinsi Sumatera Utara dan mengambil sampel sebanyak 56 responden. Jenis data yang digunakan berupa data kualitatif dan kuantitatif, sumber data yang digunakan berupa data primer. Tehnik pengumpulan data berupa kuisioner dan studi dokumentasi. Data yang diperoleh dilakukan analisis kualitas data, analisis regresi linear berganda dan pengujian hipotesis dengan bantuan SPSS 20.0.Hasil analisis menunjukan pengalaman kerja berpengaruh positif signifikan terhadap kualitas audit, kompetensi auditor berpengaruh positif signifikan terhadap kualitas audit, dan secara simultan pengalaman kerja dan kompetensi auditor berpengaruh positif signifikan terhadap kualitas audit.
\end{abstract}

\section{Kata Kunci: Pengalaman Kerja, Kompetensi Auditor, dan Kualitas Audit}

\begin{abstract}
This research aims to determine the influence of work experience and competence of auditors on audit quality. This research uses an associative approach. The population in this study was 116 auditors who worked in the office of BPKP representative of North Sumatera province and sampled as many as 56 respondents. The data types used are qualitative and quantitative data, the data sources used are primary data. Data collection techniques in the form of questionnaire and documentation studies. Data obtained is conducted data quality analysis, multiple linear regression analysis and hypothesis testing with the help of SPSS 20.0. The results of the analysis showed a significant positive effect on the quality of audit, the auditor's competence significantly positive to the quality of auditing, and simultaneously the working experience and competency of the auditor positively To audit quality.
\end{abstract}

Keywords: work experience, competency Auditor, and Audit quality

\section{PENDAHULUAN}

Tuntutan pelaksanaan akuntabilitas sektor publik dan terwujudnya good governance dalam dua dasawarsa terakhir ini semakin meningkat. Akuntabilitas sektor publik terkait 
LIABILITIES (JURNAL PENDIDIKAN AKUNTANSI)

e-ISSN 2620-5866

Volume 3. No.1 April 2020 (1-13)

Doi 10.30596/liabilities.v3i1.3880

dengan perlunya dilakukan

objek pemeriksaan. Hal ini terkait transparansi dan pemberian

informasi kepada publik dalam rangka pemenuhan hak-hak publik. Menurut Mardiasmo (2018), terdapat tiga aspek utama yang mendukung terciptanya pemerintahan yang baik (good governance) yaitu, pengawasan, pengendalian dan pemeriksan. BPKP sesuai amanat Peraturan Presiden Nomor 192 Tahun 2014 tentang Badan Pengawasan Keuangan dan Pembangunan (BPKP), merupakan Aparat Pengawasan Intern Pemerintah (APIP) yang bertanggung jawab langsung kepada Presiden, dimana ditegaskan bahwa untuk melaksanakan pembangunan nasional, anggaran pendapatan dan belanja negara/daerah secara transparan, akuntabel dan bebas dari korupsi. Presiden memerlukan fungsi pengawasan intern yang handal dan sistem pengendalian intern yang memadai.

Kualitas audit yang dilaksanakan oleh auditor inspektorat saat ini masih menjadi sorotan banyak pihak, antara lain oleh masyarakat dan auditee sebagai dengan masih banyaknya temuan audit yang tidak terdeteksi oleh auditor inspektorat pemerintah sebagai auditor internal akan tetapi ditemukan oleh auditor eksternal yaitu Badan Pengawas Keuangan (BPK) atau pihak swasta. Kualitas audit sebagai penilaian oleh pasar dimana terdapat kemungkinan auditor akan memberikan temuan mengenai suatu pelanggaran dalam sistem akuntansi klien dan adanya pelanggaran dalam pencatatannya. Kualitas audit pada sektor publik terkait dengan probabilitas seorang pemeriksa atau auditor pemerintah dapat menemukan dan melaporkan suatu penyelewengan yang terjadi pada suatu instansi atau pemerintah baik pusat maupun pemerintah daerah.

Pengalaman auditor dalam melakukan audit laporan keuangan baik dari segi lamanya waktu maupun banyaknya penugasan yang pernah ditangani (Suraida, 2005). Pengalaman juga membentuk auditor mampu menghadapi dan meyelesaikan hambatan maupun persoalan dalam pelaksanaan 
LIABILITIES (JURNAL PENDIDIKAN AKUNTANSI)

e-ISSN 2620-5866

Volume 3. No.1 April 2020 (1-13)

Doi 10.30596/liabilities.v3i1.3880

tugasnya, serta mampu

1. Audit atas kasus perkara dugaan mengendalikan kecenderungan emosional terhadap pihak yang diperiksa. Semakin berpengalaman seorang auditor maka akan semakin mudah dalam mendeteksi kesalahan. Kompetensi auditor adalah kualifikasi yang dibutuhkan oleh auditor untuk melaksanakan audit dengan benar. Menurut Arens (2008, hal 43) " pernyataan standar umum pertama menyatakan bahwa audit harus dilaksanakan oleh seorang atau lebih yang memiliki keahlian teknis yang memadai sebagai auditor. Dalam melakukan audit, seorang auditor harus memiliki mutu personal yang baik, pengetahuan yang memadai, serta keahlian khusus di bidangnya (Rai, 2008). Auditor harus memiliki pengetahuan untuk memahami entitas yang diaudit, kemudian auditor harus memiliki kemampuan untuk bekerja sama dalam tim serta kemampuan dalam menganalisa permasalahan (Sukriah dkk, 2009).

Terdapat permasalahan dalam beberapa kasus dimana hasil audit BPKP diragukan. Kasus-kasus tersebut antara lain: 
Asisten III Divisi Umum Bank Sumut, divonis masing-masing 2 tahun 6 bulan penjara dengan denda Rp 50 juta dan subsider 3 bulan. Akan tetapi pihak pertama yang menerima pesanan kasus Bank Sumut ini adalah BPKP, namun tidak ditemukannya kesalahan oleh auditor BPKP menyebabkan berlarut-larutnya dalam menyerahkan hasil audit kepada Kejati Sumut. Sehingga Kejati Sumut mengambil tindakan dengan melimpahkan kasus Bank Sumut kepada Kantor Akuntan Publik (KAP) untuk melakukan audit, dan kasus ini pun akhirnya berhasil diungkap oleh Kantor Akuntan Publik (KAP) seperti uraian diatas. Hal ini pun lantas menjadi sorotan masyarakat tentang kualitas audit yang ada pada BPKP saat ini.

2. Audit BPKP atas kasus perkara dugaan tindak pidana korupsi dana rekening air PDAM Tirtanadi pada Bank Syariah Mandiri Kantor Cabang Pembantu (KCP) Iskandar Muda. Audit ini dilakukan berdasarkan permintaan pihakkepolisian Poldasu. Kerugian negara dalam kasus ini mencapai $\mathrm{Rp} 2,9$ miliar. Kasus ini menyeret banyak nama, mulai dari Subdarkan Siregar selaku mantan Ketua Koperasi Karyawan (Kopkar) PDAM Tirtanadi, Rudi Purwanto selaku mantan BSM KCP Iskandar Muda, Adri Prasetyo selaku mantan Marketing Support BSM, Bayu Yoga Wardana selaku mantan Asisten Marketing, Adi Wardiastuti selaku mantan Bendahara Kopkar PDAM Tirtanadi dan Dimas Eko selaku mantan Kasi Simpan Pinjam. Namun setelah kasus PDAM Tirtanadi ini selesai diaudit banyak pihak yang mempertanyakan hasil auditnya. Karena adanya kesalahan laporan dan informasi yang diberikan oleh auditor dalam mengungkapkan kasus PDAM Tirtanadi mengakibatkan terdapat dua hasil audit yang berbeda yang dikeluarkan BPKP Sumut atas kasus korupsi dana rekening air 
LIABILITIES (JURNAL PENDIDIKAN AKUNTANSI)

e-ISSN 2620-5866

Volume 3. No.1 April 2020 (1-13)

Doi 10.30596/liabilities.v3i1.3880

yang melibatkan Direktur

Utama PDAM Tirtanadi, yakni

Azzam Rizal.

Dampak yang ditimbulkan adalah kualitas audit BPKP menjadi semakin diragukan, terutama dari sudut pandang masyarakat dan auditee. Standar Pemeriksaan Keuangan Negara

menjelaskan bahwa auditor harus memiliki kompetensi profesional yang memadai untuk melaksanakan tugas pemeriksaan. Asosiasi Auditor Intern Pemerintah Indonesia (2013) juga menekankan pentingnya kompetensi auditor yang juga harus disertai dengan pendidikan, pengetahuan, keahlian dan keterampilan, pengalaman, serta kompetensi lain yang diperlukan untuk melaksanakan tanggung jawabnya.

Rumusan masalah pada penelitian ini adalah :

1. Apakah pengalaman kerja memiliki pengaruh terhadap kualitas audit pada BPKP Perwakilan Provinsi Sumatera Utara? 
a. Telah bekerja lebih dari 2 tahun

b. Telah mengikuti pendidikan dan pelatihan minimal 2 kali

c. Pendidikan terakhir minimal S1

\section{HASIL DAN PEMBAHASAN}

\section{A. Gambaran Umum Responden}

Karateristik responden dalam penelitian ini dapat dilihat berdasarkan jenis kelamin, usia, tingkat pendidikan, jabatan, lama bekerja, dan pelatihan yang ditempuh dari responden dalam penelitian pada tabel dibawah ini:

Tabel 1, Jenis Kelamin

\begin{tabular}{|c|c|c|c|c|c|}
\hline \multirow{4}{*}{ Valid } & & Frequen & Percant: & Väic Percent: & $\begin{array}{l}\text { Cuntulative } \\
\text { Percent: }\end{array}$ \\
\hline & Pril & i5 & 62,5 & 62.5 & 62,5 \\
\hline & Wharit: & 21 & 37,5 & 37,5 & 1000 \\
\hline & Total & 56 & 1000,0 & 100,0 & \\
\hline
\end{tabular}

Berdasarkan tabel 1 diketahui dari 56 responden yang diteliti sebanyak 35 orang atau $62,5 \%$ berjenis kelamin pria, sementara 21 orang atau $37,5 \%$ berjenis kelamin wanita. Dapat disimpulkan bahwa mayoritas respoden dalam penelitian ini lebih banyak didominasi pada jenis kelamin pria.
Iabel2. Isis

\begin{tabular}{|c|c|c|c|c|}
\hline & Frequenc: & Pexoult & Vaic Pexent: & $\begin{array}{c}\text { Curnative } \\
\text { Peved }\end{array}$ \\
\hline Valid $26-3 \mathrm{j}$ Iahn & 12 & 21,4 & 21,4 & 21,4 \\
\hline $36-55$ Takmn & 35 & 32,5 & 32,5 & 839 \\
\hline >55 Tahm & 9 & $16: 1$ & 16,1 & 100 \\
\hline Total & 55 & 190,0 & 100,0 & \\
\hline
\end{tabular}

Berdasarkan tabel 2 diketahui dari 56 responden yang diteliti sebanyak 12 orang atau $21,4 \%$ responden berusia 26-35 tahun, 35 orang atau $62,5 \%$ responden berusia 36-55 tahun dan 9 orang atau $16,1 \%$ responden berusia > 55 tahun. Dapat disimpulkan bahwa mayoritas respoden dalam penelitian ini lebih banyak didominasi usia 36-55 tahun.

Tabel3, Tuggat Pendidikall

\begin{tabular}{|c|c|c|c|}
\hline Freganter & Percent & Vilid Peecet & $\begin{array}{l}\text { Comulative } \\
\text { Percalt }\end{array}$ \\
\hline Valid S! 53 & 91,5 & 91.5 & 91,6 \\
\hline \$2 & 5,1 & 5,1 & 100,0 \\
\hline Total & 100,0 & 100,0 & \\
\hline
\end{tabular}

Berdasarkan tabel 3

diketahui dari 56 responden yang diteliti sebanyak 53 orang atau 94,6\% responden berpendidikan S1 dan 3orang atau $5,4 \%$ responden berpendidikan $\mathrm{S} 2$. Dapat disimpulkan bahwa mayoritas respoden dalam penelitian ini lebih banyak didominasi pendidikan $\mathrm{S} 1$. 
LIABILITIES (JURNAL PENDIDIKAN AKUNTANSI)

e-ISSN 2620-5866

Volume 3. No.1 April 2020 (1-13)

Doi 10.30596/liabilities.v3i1.3880

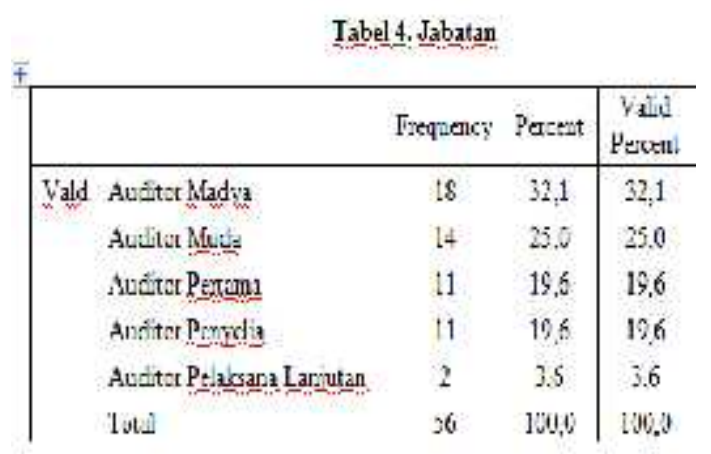

Berdasarkan tabel 4 diketahui dari 56 responden yang diteliti sebanyak 18 orang atau $32,1 \%$ responden pada tingkat jabatan Auditor Madya, 14 orang atau $25 \%$ responden pada tingkat jabatan Auditor Muda, 11 orang atau $19,6 \%$ responden pada tingkat jabatan Auditor Pertama, 11 orang atau $19,6 \%$ responden pada tingkat jabatan Auditor Penyelia dan 2 orang atau $3,6 \%$ responden pada tingkat jabatan Auditor Pelaksana Lanjutan. Dapat disimpulkan bahwa mayoritas respoden dalam penelitian ini lebih banyak didominasi pada tingkat jabatan Auditor Madya.

Iobel š Lima Bekerija

\begin{tabular}{|c|c|c|c|c|}
\hline & Freguray & Prow. & Yallitetcant & $\begin{array}{l}\text { Combire } \\
\text { Perest }\end{array}$ \\
\hline Valió 1.jahr & 3 & 5,4 & 54 & $5, t$ \\
\hline 5HoThun & 6 & 0.7 & 12.7 & 15. \\
\hline 20Thann & 47 & 19,9 & 899 & 1000 \\
\hline Jetal & 35 & 100 & 100 & \\
\hline
\end{tabular}

Berdasarkan tabel 5 diketahui dari 56 responden yang diteliti, 3 orang atau $5,4 \%$ responden bekerja dengan lama
1-5 tahun, 6 orang atau $10,7 \%$ bekerja dengan lama 5-10 tahun dan 47 orang atau $83,9 \%$ bekerja dengan lama > 10 tahun. Dapat disimpulkan bahwa mayoritas respoden dalam penelitian ini lebih banyak didominasi bekerja dengan lama > 10 tahun.

\section{Tabel 5, Lama Belecrin}

\begin{tabular}{|c|c|c|c|c|}
\hline & & & & Cumulative \\
\hline & Fiejuercy & Percerl & Yaid Pescent & Percert \\
\hline aid 13 lym & 3 & 3.1 & 3,1 & 3.1 \\
\hline 5-10 Thabim & 6 & 107 & $10 . ?$ & $1 \kappa 1$ \\
\hline$-10 \mathrm{Tghim}$ & 47 & 83,9 & $83, ?$ & $\min 2$ \\
\hline Total & $5 s$ & 109,0 & 100,0 & \\
\hline
\end{tabular}

Berdasarkan tabel 5 diketahui dari 56 responden yang diteliti, 3 orang atau $5,4 \%$ responden bekerja dengan lama 1-5 tahun, 6 orang atau 10,7\% bekerja dengan lama 5-10 tahun dan 47 orang atau $83,9 \%$ bekerja dengan lama > 10 tahun. Dapat disimpulkan bahwa mayoritas respoden dalam penelitian ini lebih banyak didominasi bekerja dengan lama $>10$ tahun.

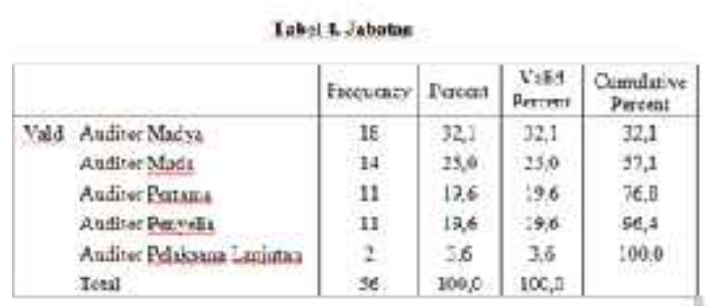

Berdasarkan tabel 6 diketahui dari 56 responden yang diteliti 
e-ISSN 2620-5866

Volume 3. No.1 April 2020 (1-13)

Doi 10.30596/liabilities.v3i1.3880

\begin{abstract}
sebanyak 15 orang atau $26,8 \%$ responden telah mengikuti pelatihan sebanyak 3 kali, 6 orang atau $10,7 \%$ responden telah mengikuti pelatihan sebanyak 4 kali, 3 orang atau 5,4\% responden telah mengikuti pelatihan sebanyak 5 kali, dan 32 orang atau $57,1 \%$ responden telah mengikuti pelatihan sebanyak > 5 kali. Dapat disimpulkan bahwa mayoritas respoden dalam penelitian ini lebih banyak didominasi telah mengikuti pelatihan sebanyak > 5 kali.
\end{abstract}

\section{B. Analisis Regresi Linear Berganda}

Hasil pengolahan menggunakan data SPSS pada multiple regression analysis tentang pengaruh Pengalaman Kerja (X1) dan Kompetensi (X2) terhadap Kualitas Audit (Y) maka dapat dilihat pada tabel berikut ini :
Tabel7. RegresiLimear Berganda

\begin{tabular}{|c|c|c|c|c|c|}
\hline \multirow{3}{*}{ de } & \multicolumn{3}{|c|}{ Coffticints $^{2}$} & \multirow[b]{3}{*}{ I } & \multirow[b]{3}{*}{ Sis } \\
\hline & \multicolumn{3}{|c|}{ 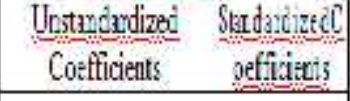 } & & \\
\hline & B & Std. Erer & Betr & & \\
\hline (Constant) & 19,599 & 9,158 & & 3,298 & $=000$ \\
\hline Pengalaman Kera & 973 & 291 & 549 & 4,996 & 900 \\
\hline Kecretemsit Anätor & 453 & 116 & $A B:$ & 3,475 & $m_{4}$ \\
\hline
\end{tabular}

Dari tabel 7 dapat dilihat persamaan regresi linear ganda untuk Pengalaman Kerja dan Kompetensi Auditor adalah :

$$
Y=19,579+0,973 X 1+0,463 X 2
$$

Persamaan di atas memperlihatkan bahwa semua variabel bebas (Pengalaman Kerja dan Kompetensi Auditor) memiliki koefisien yang positif, berarti seluruh variabel bebas mempunyai pengaruh yang searah terhadap variabel Y (Kualitas Audit). Koefisien Pengalaman Kerja memberikan nilai sebesar 0,973 yang berarti bahwa jika Pengalaman Kerja semakin baik dengan asumsi variabel lain tetap maka Kualitas Audit akan mengalami peningkatan. Begitu juga dengan koefisien Kompetensi Auditor memberikan nilai sebesar 0,463 yang memiliki arti bahwa jika Kompetensi Auditor bertambah dan semakin baik dengan asumsi nilai 
LIABILITIES (JURNAL PENDIDIKAN AKUNTANSI)

e-ISSN 2620-5866

Volume 3. No.1 April 2020 (1-13)

Doi 10.30596/liabilities.v3i1.3880

yang lain tetap, maka variabel

kualitas audit juga akan mengalami peningkatan.

(b) Kompetensi

Auditor berpengaruh terhadap Kualitas Audit

\section{Pengujian Hipotesis}

\section{Uji t (Regresi Parsial)}

Uji t dilakukan untuk melihat apakah ada hubungan yang signifikan atau tidak dalam hubungan antara X1 dan X2 terhadap Y.

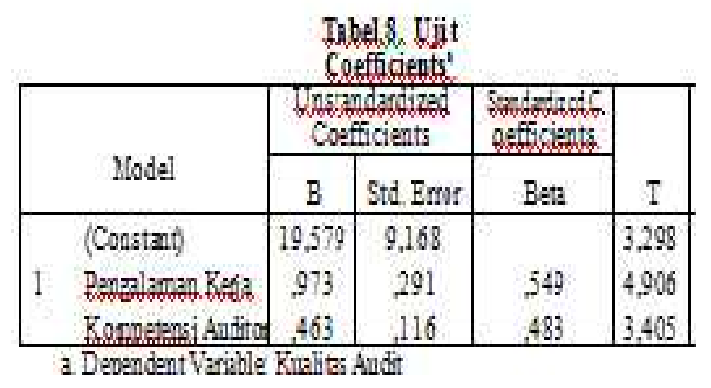

Berdasarkan tabel 8 diatas :

\section{(a) Pengalaman Kerja berpengaruh terhadap \\ Kualitas Audit}

Hasil pengujian diperoleh nilai thitung sebesar 4,906 untuk variabel Pengalaman Kerja dengan tingkat signifikansi 5\% diperoleh nilai t-tabel 2,005. Maka nilai t-hitung > t-tabel yaitu $4,906>2,005$ dengan nilai signifikasi sebesar $0,000<0,05$ yang berarti bahwa Pengalaman Kerja berpengaruh positif signifikan terhadap Kualitas Audit maka H0 diterima.

\begin{abstract}
Hasil pengujian diperoleh nilai thitung sebesar 3,405 untuk variabel Kompetensi Auditor dengan tingkat signifikansi $5 \%$ diperoleh nilai t-tabel 2,005. Maka nilai t-hitung > t-tabel yaitu 3,405 > 2,005 dengan nilai signifikasi sebesar 0,004 $<0,05$ yang berarti bahwa Kompetensi Auditor berpengaruh signifikan positif terhadap Kualitas Audit maka H0 diterima.
\end{abstract}

\section{Uji F (Regresi Simultan)}

Hasil perhitungan regresi secara simultan diperoleh pada tabel 9 sebagai berikut :

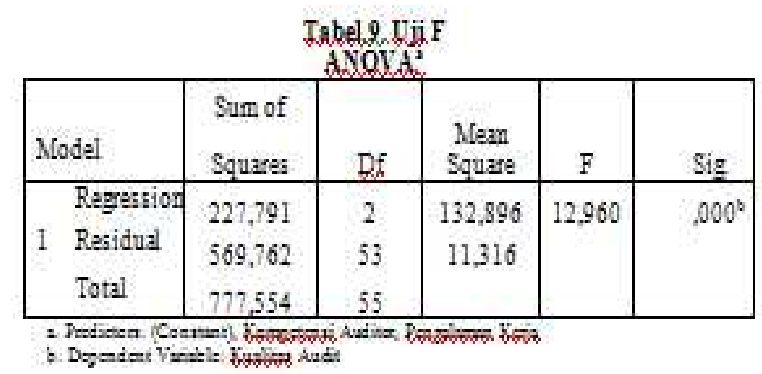

Dari hasil data di atas terlihat bahwa nilai F-hitung sebesar 12,960 dengan tingkat signifikansi 5\% diperoleh nilai F-tabel 3,17. Maka F-hitung > F-tabel yaitu 12,960> 3,17 dengan 
LIABILITIES (JURNAL PENDIDIKAN AKUNTANSI)

e-ISSN 2620-5866

Volume 3. No.1 April 2020 (1-13)

Doi 10.30596/liabilities.v3i1.3880

nilai signifikan sebesar $0,000<0,05$

kesimpulannya adalah Pengalaman

Kerja dan Kompetensi berpengaruh signifikan terhadap Kualitas Audit maka H0 diterima.

\section{PEMBAHASAN}

\section{Pengaruh Pengalaman Kerja terhadap Kualitas Audit}

Hasil pengujian hipotesis menunjukkan bahwa Pengalaman Kerja berpengaruh signifikan terhadap kualitas audit. Hal ini menunjukkan bahwa personel audit yang berpengalaman menggunakan analisis yang lebih teliti, terinci dan runtun dalam mendeteksi gejala kekeliruan dibandingkan dengan yang tidak berpengalaman. Menurut Alim (2007) dan Andrean (2014) bahwa semakin lama masa kerja dan pengalaman yang dimiliki auditor maka akan semakin baik dan meningkat pula kualitas audit yang dihasilkan. Hal ini sesuai dengan penelitian terdahulu yang dilakukan oleh Sukriah ika (2009), Yunus Fiscal (2012) dan Rinhard (2017) menyimpulkan bahwa adanya pengaruh signifikan pengalaman kerja terhadap kualitas audit.

\section{Pengaruh Kompetensi Auditor terhadap Kualitas Audit}

Hasil pengujian hipotesis menunjukkan bahwa Kompetensi Auditor berpengaruh signifikan terhadap kualitas audit. Hal ini menunjukkan bahwa auditor harus memiliki pengetahuan untuk memahami entitas yang diaudit dan auditor harus memiliki kemampuan untuk bekerja sama dalam tim serta kemampuan dalam menganalisa permasalahan sehingga auditor dapat melakukan audit dengan teliti, cermat, dan obyektif. Menurut Christiawan (2002) dan Alim (2007) jika seorang auditor mempunyai kompetensi yang tinggi maka akan semakin baik kualitas auditnya. Hal ini sesuai dengan penelitian terdahulu yang dilakukan oleh Sukriah ika (2009), Prihartini (2015), dan Rainhard (2017) yang menyimpulkan bahwa adanya pengaruh signifikan kompetensi auditor terhadap kualitas audit.

\section{Pengaruh Pengalaman Kerja dan Kompetensi Auditor terhadap Kualitas Audit}


LIABILITIES (JURNAL PENDIDIKAN AKUNTANSI)

e-ISSN 2620-5866

Volume 3. No.1 April 2020 (1-13)

Doi 10.30596/liabilities.v3i1.3880

Hasil pengujian hipotesis menunjukkan bahwa Pengalaman Kerja dan Kompetensi Auditor berpengaruh signifikan terhadap kualitas audit. Hal ini menunjukkan bahwa auditor merupakan profesi yang sangat dibutuhkan untuk meningkatkan keandalan atas laporan keuangan yang dibuat oleh sebuah perusahaan sehingga dapat memberikan informasi yang andal dan reliabel kepada pihak yang berkepentingan atas laporan keuangan tersebut. Auditor harus memiliki tingkat kemahiran umum dalam memberikan kualitas audit yang baik terhadap pihak yang berkepentingan akan laporannya. Pertama, pengalaman kerja, semakin berpengalaman seorang auditor dalam melaksanakan perkerjaannya dalam mendeteksi kecurangan yang ada maka akan semakin kritislah auditor dalam melakukan pengujian bukti audit. Kedua, kompetensi, sikap auditor yang berkompeten menghasilkan kualitas audit yang sesuai dengan harapan. Kompetensi yang dimiliki oleh seorang auditor menjadikan auditor berkerja secara baik.

\section{KESIMPULAN DAN SARAN}

\section{Kesimpulan}

Pengalaman kerja memiliki pengaruh positif dan signifikan terhadap kualitas audit pada BPKP Perwakilan Provinsi Sumatera Utara. Terbukti dengan perolehan hasil nilai t-hitung sebesar 4,906 dan nilai t-tabel sebesar 2,005. Kompetensi memiliki pengaruh positif dan signifikan terhadap Kualitas Audit pada BPKP Perwakilan Provinsi Sumatera Utara. Terbukti dengan perolehan hasil nilai t-hitung sebesar 3,405 dan nilai ttabel sebesar 2,005. Pengalaman Kerja dan Kompetensi Auditor memiliki pengaruh yang signifikan terhadap Kualitas Audit pada BPKP Perwakilan Provinsi Sumatera Utara, terbukti dengan perolehan hasil nilai F-hitung sebesar 12,960 dan nilai Ftabel sebesar 3,17. Nilai hasil uji determinasi diperoleh sebesar $41 \%$ hal ini menunjukkan bahwa pengalaman kerja dan kompetensi auditor mempengaruhi kualitas audit sebesar $41 \%$ dan sisanya $59 \%$ dipengaruhi oleh faktor-faktor lain.

\section{Saran}


LIABILITIES (JURNAL PENDIDIKAN AKUNTANSI)

e-ISSN 2620-5866

Volume 3. No.1 April 2020 (1-13)

Doi 10.30596/liabilities.v3i1.3880

Bagi peneliti selanjutnya disarankan menambahkan variabel lain yang berkaitan erat secara teori terhadap kualitas audit dan bagi BPKP Perwakilan Provinsi Sumatera Utara dalam usaha meningkatkan kualitas audit, auditor dan pimpinan berserta bagian yang terkait lainnya agar dapat meningkatkan pengalaman kerja dan kompetensi auditor untuk mewujudkan good governance.

\section{DAFTAR PUSTAKA}

Andreani Hanjani (2014). Pengaruh Etika Auditor, Pengalamana Auditor, Fee Audit, dan Motivasi Auditor terhadap Kualitas Audit (Studi pada Auditor KAP di Semarang). Jurnal Akuntansi. Universitas Diponegoro. Vol. 3, No.2

Arens, Alvin A. Elder, Randal J dan Beasley, Marks S. (2008). Auditing dan Jasa Assurance. Jilid 1. Edisi Keduabelas. Jakarta : Erlangga.

Asih, Dwi Ananiang Tyas (2006) .

Pengaruh

Terhadap

Pengalaman

Keahlian Auditor Dalam Bidang Auditing. Skripsi Akuntansi. Fak. Ekonomi UIN Yogyakarta.

Asosiasi Auditor Intern Pemerintah Indonesia (2013). Standar Audit Intern Pemerintah Indonesia. Jakarta: AAIPI.
Aziz Husein Hasibuan (2016a). "Audit Kerugian Negara Korupsi Bank Sumut Macet di BPKP".

http://medan.tribunnews.com.

"Audit Kerugian Negara
Korupsi Bank Sumut di BPKP
Tak Kunjung Rampung".
http://medan.tribunnews.com.
Azuar Juliandi dkk. (2015). Metodologi Penelitian Bisnis. Penerbit: UMSU PRESS.

Badjuri, Achmad. (2012). Analisis Faktor-Faktor yang Mempengaruhi Kualitas Hasil Pemeriksaan Audit Sektor Publik (Studi Empiris pada BPKP Perwakilan Jawa Tengah). Jurnal Akuntansi Keuangan dan Perbankan. Vol. 1, No. 2

Boynton, William C., Jhonson Raymond, dan Walter G. Kell. (2001). Modern Auditing. Seventh Edition. Sussex: John Wiley and Sons, Inc.

BPK (2017). Standar Pemeriksaan Keuangan Negara. Jakarta: BPK.

BPK-RI. (2007). Standar Pemeriksaan Keuangan Negara (SPKN) 2007. (

Cristiawan, Yulius Yogi (2002). Kompetensi dan Independensi Akuntan Publik. Jurnal Akuntansi dan Keuangan, Vol. 4 No. 2 Hal. 79-92.

Fiscal, Yunus dkk, (2012). Pengaruh pengalaman kerja dan 
kompetensi auditor terhadap kualitas audit (Studi kasus pada kantor BPKP Bandar Lampung). Jurnal Akuntansi dan Keuangan. Vol. 3, No. 1, Maret 2012.

Ghozali, Imam. (2010). Aplikasi Analisis Multivariate dengan program SPSS. Cetakan IV. Badan Penerbit Universitas Diponegoro. Semarang.

IAI, (2001). Standar Profesi Akuntan Publik, Jakarta: Salemba Empat.

Indah, S. N. 2010. Pengaruh Kompetensi dan Independensi Auditor Terhadap Kualitas Audit (Studi Empiris Pada Auditor KAP di Semarang). Skripsi. Universitas Diponegoro. Semarang.

Libby, R., dan Frederick, D.M. (1990). Experience and The Ability to Explain Audit Findings. Journal of Accounting Research, Vol. 28, pp: 348-367.

Mardiasmo. 2018. Akuntansi Sektor Publik Edisi 2. Penerbit Andi. Yogyakarta Mardiasmo, (2018). Otonomi dan Manajemen Keuangan Daerah, Yogyakarta: BPFE UGM.

Metro 24 Jam (2017). "Perkara Korupsi Kredit Fiktif, mantan dirut PDAM Tirtanadi Diminta Jadi Saksi". http://news.metro24jam.com
Mulyadi, (2009). Auditing. Edisi 6. Jakarta: Salemba Empat.

Peraturan Mentri Pendayagunaan Aparatur Negara Nomor PER/05/M.PAN/03/2008.

Pusdiklatwas BPKP (2010). Modul diklat standar kompetensi. Pusat pendidikan dan pengawasan Keuangan dan Pembangunan Sumut.

Prihartini, (2015). Pengaruh Kompetensi, Independensi, Objektivitas, Integritas dan Akuntabilitas Terhadap Kualitas Audit di Pemerintah Daerah. Skrisi USU.

Quenna, Precilia Prima dan Rohma, Abdul, (2012). Analisis FaktorFaktor yang Mempengaruhi Kualitas Audit Aparat Inspektorat Kota/Kabupaten di Jawa Tengah. Journal of Accounting. Vol.1 No. 2, Hal $1-12$.

Rai, I Gusti Agung, (2008). Audit Kinerja pada Sektor Publik. Jakarta: Salemba Empat.

Rainhard (2017). Pengaruh Kompetensi, Pengalaman Kerja, Integritas, Independensi, dan Gaya Kepemimpinan Terhadap Kualitas Audit Pada BPKP Provinsi Sulewesi Tenggara. Skripsi Akuntansi. Fak. Ekonomi dan Bisnis. Universitas Hasanuddin.

Robedo Gusti (2017). "Korupsi Mantan PPK Bank Sumut Divonis 2,5 Tahun Penjara" http://www.rmolsumut.com. 
LIABILITIES (JURNAL PENDIDIKAN AKUNTANSI)

e-ISSN 2620-5866

Volume 3. No.1 April 2020 (1-13)

Doi 10.30596/liabilities.v3i1.3880

Sugiono, (2016). Metodologi Penelitian Kuantitatif, Kualitatif dan $R \& D$, Bandung: Alfabeta.

Sumut pos (2014). "Auditor BPKP Ditenggrangi Curang". http://medan.sumutpos.com.

Sukriah, Ika., Akram., Biana Adha Inapty. 2009. Pengaruh Pengalaman Kerja, Independensi, Obyektifitas, Integritas dan Kompetensi Terhadap Kualitas Hasil Pemeriksaan. Simposium Nasional Akuntansi XII. Palembang.

Suraida, Ida, (2005). Pengaruh Etika, Kompetensi, Pengalaman Audit dan Risiko Audit Terhadap Skepitisme Profesional Auditor dan Ketetapan Pemberian Opini Akuntan Publik. Jurnal Sosiohumaniro. Vol. 7, No.3.

Top Metro (2017). " Mantan Divisi Bank Sumut Divonis 2,6 Tahun penjara" https://topmetro.news. 